\title{
EFFECT OF FERTILIZER AND MANURE ON THE MOVEMENT OF NPKS IN RICE SOILS OF MADHUPUR TRACT AND MEGHNA RIVER FLOODPLAIN
}

\author{
M. A. Khan ${ }^{1 *}$, M. A. Islam ${ }^{1}$, A. S. M. F. Bari ${ }^{1}$ and S. Akter ${ }^{2}$ \\ ${ }^{1}$ Department of Soil Science, Sher-e-Bangla Agricultural University, Dhaka-1207, Bangladesh \\ 2Biotechnology Division, Bangladesh Institute of Nuclear Agriculture, Mymensingh-2202, Bangladesh \\ *Corresponding author, E-mail: makhan_sau@ymail.com
}

(Received: 21 December 2017, Accepted: 29 January 2018)

Keywords: nutrient leaching, yield, nutrient accumulation, soil diversity

\begin{abstract}
The experiment was conducted in a net house of Sher-e-Bangla Agricultural University, $\left(23^{\circ} 35^{\prime} \mathrm{N}\right.$ latitude and $90^{\circ} 35^{\prime} \mathrm{E}$ longitude) Dhaka, Bangladesh during November - May to study the effect of fertilizer and manure on the yield of boro rice and movement of nutrients through undisturbed soil columns. The experiment consists of 2 factors, i.e. soils and fertilizer plus manure. Two soils $\left(\mathrm{S}_{1}=\mathrm{SAU}\right.$ Soil and $\mathrm{S}_{2}=$ Sonargaon Soil) with 4 levels of fertilizer plus manure, as $\mathrm{T}_{0}$ : Control, $\mathrm{T}_{1}$ : $100 \%$ $\mathrm{N}_{120} \mathrm{P}_{20} \mathrm{~K}_{45} \mathrm{~S}_{20}$ (Recommended dose), $\mathrm{T}_{2}$ : 50\% NPKS + $5 \mathrm{t} \mathrm{ha}^{-1}$ cowdung, $\mathrm{T}_{3}: 50 \%$ $\mathrm{NPKS}+2.1 \mathrm{t} \mathrm{ha}^{-1}$ poultry manure were imposed during boro (winter) season. Boro rice (BRRI dhan29) was grown in the soil cores, and fertilizer and manure treatments were applied to the soils. Higher and statistically similar grain yields of boro rice were found from $T_{1}, T_{2}$, and $T_{3}$ fertilizer treatments. The highest grain yield was found where $50 \% \mathrm{NPKS}+5 \mathrm{t} \mathrm{ha}^{-1}$ cowdung were used in the Sonargaon soil. Higher grain $\mathrm{N}, \mathrm{P}$ and $\mathrm{K}$ concentrations were obtained in the treatment combination where fertilizer plus manure were applied in two soils. Higher leachate N, P and K concentrations were found in 100\% chemical fertilizer treatment. The $\mathrm{N}$ leaching increased up to 45 DAT and then declined while the $\mathrm{P}$ and $\mathrm{K}$ leaching increased up to 35 DAT and then decreased. Higher $\mathrm{pH}$ values were found in the $10-20 \mathrm{~cm}$ depth of post-harvest soils in comparison to $0-10 \mathrm{~cm}$. The higher $\mathrm{pH}$ values were found in soils where $50 \%$ NPKS + $2.1 \mathrm{t} \mathrm{ha}^{-1}$ poultry manure applied. The level of $\mathrm{P}$ more increased in the depths of $0-10$ $\mathrm{cm}$ of SAU soil where fertilizer or fertilizer plus manure were applied and the $\mathrm{P}$ concentrations more increased in the depth of $10-20 \mathrm{~cm}$ where fertilizer plus manure were applied in SAU soil. The level of S more increased in the depths of $0-10 \mathrm{~cm}$ and $10-20 \mathrm{~cm}$ of $\mathrm{S}_{2} \mathrm{~T}_{2}$ and $\mathrm{S}_{2} \mathrm{~T}_{3}$ treatment combination where fertilizer plus manure applied in Sonargaon soil. Similar levels of $\mathrm{N}$ and $\mathrm{K}$ concentrations were observed in the initial and post-harvest soils.
\end{abstract}

\section{Introduction}

The soil fertility depletion is a major problem to higher crop production in Bangladesh. The increasing cropping intensity has resulted in a great exhaustion of nutrients in soils. Rice-rice cropping system is the most important cropping pattern in Bangladesh. Among the three types of rice, boro rice covers about $56.66 \%$ of total rice area and it contributes to $43.24 \%$ of the total rice production in the country (BBS, 2008). The application of fertilizer and manure play an important role in the production of dry season winter rice (locally called, boro rice). It will, therefore, be necessary to place greater emphasis on strategic research to increase the 
Khan et al.

efficiency of applied nutrients through integration with organic manures, which will help in accomplishing twin objectives of sustaining soil health and ensuring food security and environmental protection.

Application of manure and fertilizer affects the nutrient movement in soil. The available nutrient moves downward with percolated water. The bioavailability and movement of nutrients in the soil are dependent on some factors including the source and concentration of the nutrient, soil properties such as clay content, $\mathrm{pH}$ and redox conditions, ions and type and amount of organic matter. The mobility of nutrient through the percolated water was evaluated by this experiment and the effect of manure and fertilizer on the growth and yield of boro rice were evaluated. Organic matter decomposition and nutrients mineralization are greatly affected by the soil moisture level (Guntinas et al., 2012). Anaerobic condition in paddy soil leads to mobilization of some nutrients and thus affects nutrients bio availability to rice plants (Fageria et al., 2011).

The transport of nitrogen $(\mathrm{N})$, phosphorus $(\mathrm{P})$, potassium $(\mathrm{K})$ and sulfur $(\mathrm{S})$ in soil is governed by the difference of soil and the variation of added fertilizer. Application of chemical fertilizers with farmyard manure increased $\mathrm{N}, \mathrm{P}$ and $\mathrm{K}$ uptake by rice plants and increased grain yield of rice (Yang et al., 2004). The mobility of N, P, K and S in soil is still not thoroughly understood. There is the possibility of preferential flow of $\mathrm{K}$ in the undisturbed soil cores due to lack of $\mathrm{K}$ sorption (Jalali and Rowell, 2009). Repeated application of organic forms of P could lead to significant leaching of P to ground water (Anderson and Magdoff, 2005).

Little work has been done on the fate of applied fertilizer and manure during rice culture through undisturbed soil columns. To increase the efficiency of manure and fertilizer in rice cultivation, it is necessary to identify the suitable level and type of manure and fertilizer. The fate of added fertilizer in the soil column and estimation of nutrient leaching is important for plant nutrition and soil fertility. Soil is a heterogeneous system, and the study was undertaken to understand the effect of manure and fertilizer on yield and leaching loss of nutrients through undisturbed soil columns with rice culture.

\section{Materials and Methods}

An experiment was carried out in a net house of Sher-e-Bangla Agricultural University $\left(23^{\circ} 35^{\prime} \mathrm{N}\right.$ latitude and $90^{\circ} 35^{\prime} \mathrm{E}$ longitude) during July 2011 to May 2012 to evaluate the movement of nutrient in undisturbed soil columns with rice culture. Boro (winter) rice was grown in the core during December 2011 to May 2012 and transplanted aman (T. Aman) rice was grown in the same cores during July 2011 to November, 2011. The climate of the experimental area is characterized by a scanty rainfall associated with moderately low temperature in the rabi season (October to March, 2011-2012). Two different types of soils were collected in PVC pipes from the SAU farm and Sonargaon, Narayanganj during July, 2011. Twenty four ( 2 soils $\times 4$ fertilizer treatment $\times 3$ replication) undisturbed soil cores $(25 \mathrm{~cm}$ diameter and $40 \mathrm{~cm}$ length) were collected in PVC pipes. Initial soil samples were collected from each site and analyzed for physico-chemical properties.

The soil was taken from a rice cultivated farm with a homogenous soil. The polyvinyl chloride (PVC) pipe was pushed to the soil by creating pressure inside pipe wall and by adding water to the soil. The soil cores were transferred to the net house and processed for setting on the plastic container. Filter paper (Whatman No. 1), glass wool and a 4-cm layer of acid-washed silica sand (sieved to obtain a 1-2 $\mathrm{mm}$ particle diameter) were placed at the bottom of the plastic container that served as the base for the PVC soil core. Two holes in the plastic base 
were connected using polypropylene tubes and a $\mathrm{T}$ tube to a conical flask that was used to collect column leachate (Fig. 1).

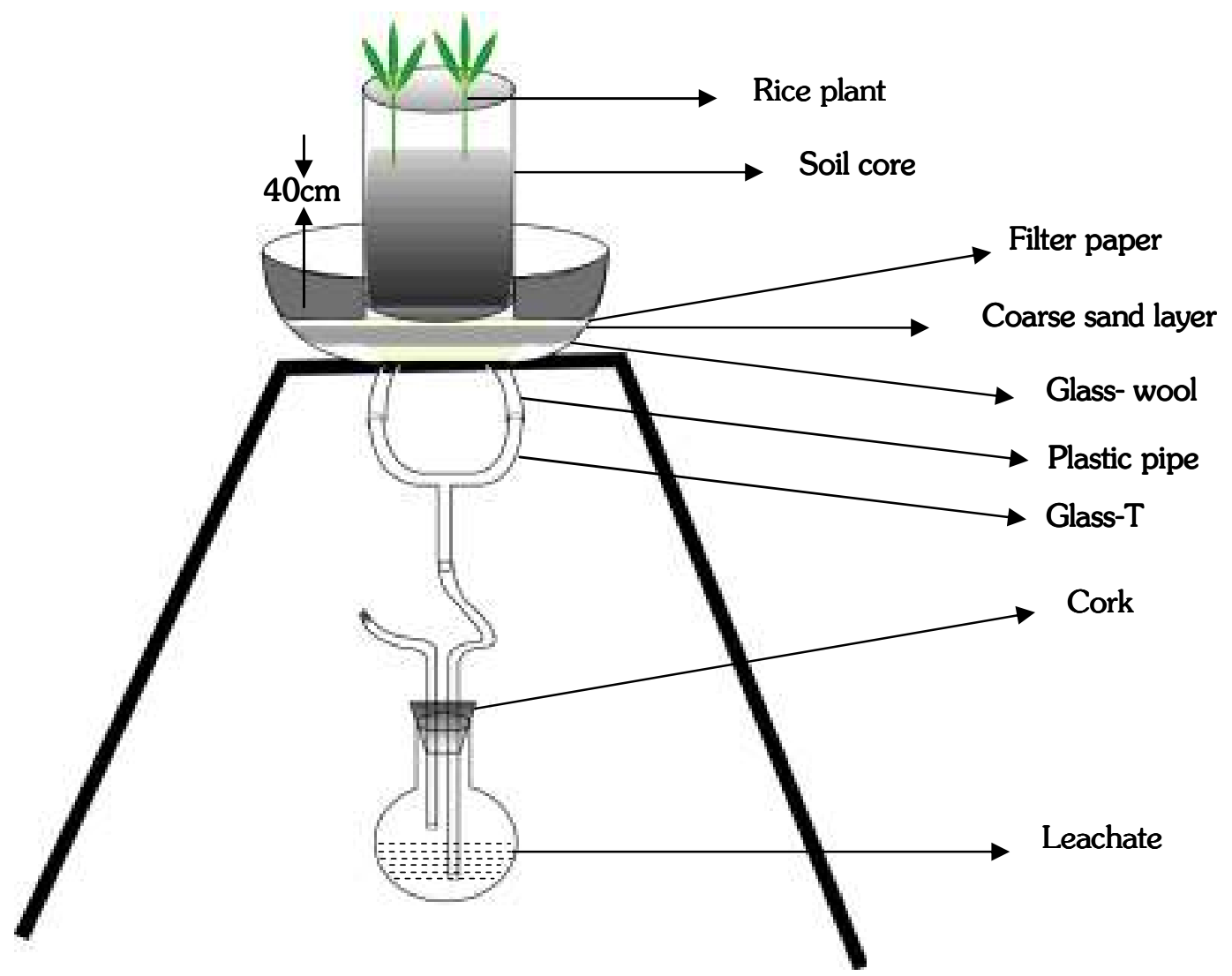

Fig. 1. Leachate collection from undisturbed soil core with fertilizer and manure application in boro rice.

Two soils (Soil-1: SAU Soil, Soil-2: Sonargaon Soil) and four fertilizer treatments ( $\mathrm{T}_{0}$ : Control, $\mathrm{T}_{1}$ : Recommended dose of fertilizer $\left(\mathrm{N}_{120} \mathrm{P}_{20} \mathrm{~K}_{45} \mathrm{~S}_{20}\right), \mathrm{T}_{2}$ : $50 \%$ NPKS +5 ton ha-1 cowdung, $\mathrm{T}_{3}: 50 \% \mathrm{NPKS}+2.1$ ton ha ${ }^{-1}$ poultry manure) were used for rice cultivation in the PVC core. The differences between SAU and Sonargaon soils were in texture (silt loam and silty clay loam), $\mathrm{pH}$ (6.4 and 7.3), extractable K (0.05 and $\left.0.06 \mathrm{cmolkg}^{-1}\right), \mathrm{P}(19.85$ and $12.00 \mathrm{ppm})$ $\mathrm{S}(14.40$ and $16.00 \mathrm{ppm})$ and total $\mathrm{N}(0.06$ and $0.07 \%)$. Sonargaon soil had higher organic carbon (1.01\%) than SAU soil (0.69\%).

The treatment wise required amounts of manures and $\mathrm{N}, \mathrm{P}, \mathrm{K}$ and $\mathrm{S}$ fertilizers per core were applied by considering the soil weight of $0-15 \mathrm{~cm}$ depth. Poultry manure had elevated $\mathrm{N}$ $(2.2 \%), \mathrm{P}(1.99 \%), \mathrm{K}(0.82 \%)$ and $\mathrm{S}(0.29 \%)$ in comparison to the $\mathrm{N}(1.46 \%) \mathrm{P}(0.29 \%) \mathrm{K}$ $(0.74 \%)$ and S $(0.24 \%)$ of cowdung. Full amounts of manure, TSP, MP and gypsum were applied at final land preparation before transplanting of rice seedlings. Urea was applied in 3 equal splits: one third was applied at basal before transplanting, one third at active tillering stage (30 DAT) and the remaining one third was applied at five days before panicle initiation stage. 
Khan et al.

Rice var. BRRI dhan29 was used as the test crop in this experiment which is recommended for Boro season. The experimental design was Randomized complete block design (RCBD) with two factors and three replicates for each treatment. The distance maintained between core to core and row to row were $40 \mathrm{~cm}$ and $1 \mathrm{~m}$ respectively. Thirty days old Boro seedlings were transplanted on the second week of December, 2011. Two seedlings for one hill were transplanted in the core. Traditional irrigation $(2-3 \mathrm{~cm}$ continuous flooding) was applied during the growing period of Boro rice crop. Intercultural operations and plant protection measures were done to ensure normal growth of the crop. Leachate samples were collected at 25, 35, 45, 55, 65 and 75 days after transplantation of Boro rice and analyzed for N, P, K and S by using standard analytical methods. The Boro crop was harvested at full maturity when $80-90 \%$ of the grains were turned into straw colored on May, 2012. The crop was cut at the ground level. After harvest, the rice yield parameters and yield were recorded.

\section{Soil and leachate analysis}

Soil samples were analyzed for both physical and chemical characteristics viz. texture, $\mathrm{pH}$, total $\mathrm{N}$ and available $\mathrm{P}, \mathrm{K}$, and $\mathrm{S}$ contents. Mechanical analysis of soil was done by hydrometer method (Bouyoucos, 1926) and the textural class was determined. Soil pH was measured with the help of a glass electrode $\mathrm{pH}$ meter (Jackson, 1962). The soil organic carbon was determined by wet oxidation method (Walkley and Black, 1935). Total soil N concentrations were determined by the Micro Kjeldahl method (Page et al., 1982).

Available $\mathrm{P}$ was determined from the soil with $0.5 \mathrm{M} \mathrm{NaHCO}_{3}$ solutions, $\mathrm{pH} 8.5$ (Olsen et al., 1954). Exchangeable $\mathrm{K}$ was determined by $1 \mathrm{~N} \mathrm{NH}_{4} \mathrm{OAc}(\mathrm{pH}$ 7) extraction method. Available $\mathrm{S}$ content was determined by extracting the soil with $\mathrm{CaCl}_{2}(0.15 \%)$ solution as described by (Page et al., 1982). The leachate samples were analyzed for $\mathrm{N}, \mathrm{P}, \mathrm{K}$ and $\mathrm{S}$ by using similar methods.

The data obtained for different parameters were statistically analyzed to find out the significant difference of different treatments on yield and yield contributing characters. The mean values of all the characters were calculated and analysis of variance was performed by the ' $\mathrm{F}$ ' (variance ratio) test. The significance of the difference among the treatment means was estimated by the Duncan's Multiple Range Test (DMRT) at 5\% level of probability (Gomez and Gomez, 1984).

\section{Results and Discussion}

\section{Effect of soils, fertilizer and manure on the yield parameters and yield of boro rice}

The effects of soil, fertilizer and manure on the yield parameters and yield of rice are presented in Table 1. The plant height, panicle length and filled grains panicle ${ }^{-1}$, grain and straw yields were not significantly influenced by the variation of soils. Sonargaon soil showed higher plant height, panicle length and number of filled grains panicle ${ }^{-1}$. The higher grain $(29.67 \mathrm{~g} / \mathrm{core})$ and straw yield (34.13 g/core) were obtained in Sonargaon soil and lower in SAU Soil (Table 1). Plant height, panicle length, filled grains panicle $e^{-1}, 1000$ grain weight and grain yield were significantly affected by fertilizer and manure treatments. Among the different fertilizer doses, $\mathrm{T}_{3}(50 \% \mathrm{NPKS}+2.1 \mathrm{t}$ poultry manure) showed the highest plant height $(79.95 \mathrm{~cm})$, which was closely followed by $\mathrm{T}_{1}$, (RDCF) $\mathrm{T}_{2}\left(50 \% \mathrm{NPKS}+5 \mathrm{t} \mathrm{ha}^{-1}\right.$ cowdung) and lowest plant height $(64.18 \mathrm{~cm})$ was observed in the $\mathrm{T}_{0}$ treatment. Higher and statistically similar number of filled grains panicle $e^{-1}$ and 1000 grain weight were noticed in the $T_{1}, T_{2}$ and $T_{3}$ fertilizer treatments. The higher straw yield $(34.90 \mathrm{~g} /$ core $)$ was recorded in $\mathrm{T}_{1}\left(\left(\mathrm{~N}_{120} \mathrm{P}_{20} \mathrm{~K}_{45} \mathrm{~S}_{20}\right)\right.$ treatment.) The 
Effect of Fertilizer and Manure on the Movement of NPKS in Rice

grain yield was significantly increased due to the application of manure and chemical fertilizers (Rahman et al., 2009).

Table 1. Effects of soil, fertilizer and soil fertilizer on the yield parameters and yield of boro rice

\begin{tabular}{|c|c|c|c|c|c|c|}
\hline Treatments & $\begin{array}{l}\text { Plant } \\
\text { height } \\
(\mathrm{cm})\end{array}$ & $\begin{array}{c}\text { Panicle } \\
\text { length }(\mathrm{cm})\end{array}$ & $\begin{array}{l}\text { No. of } \\
\text { filled } \\
\text { grain/ } \\
\text { panicle }\end{array}$ & $\begin{array}{c}1000 \\
\text { grain wt. } \\
\text { (g) }\end{array}$ & $\begin{array}{l}\text { Straw yield } \\
\text { (g/core) }\end{array}$ & $\begin{array}{c}\text { Grain yield } \\
\text { (g/core) }\end{array}$ \\
\hline \multicolumn{7}{|l|}{ Effect of Soil } \\
\hline $\mathrm{S}_{1}$ & 70.27 & 21.16 & 83.01 & 20.23 & 28.05 & 24.58 \\
\hline $\mathrm{S}_{2}$ & 73.22 & 21.94 & 95.34 & 20.52 & 34.13 & 29.67 \\
\hline $\operatorname{SE}( \pm)$ & NS & NS & NS & NS & NS & NS \\
\hline \multicolumn{7}{|c|}{ Effect of Fertilizer and Manure } \\
\hline $\mathrm{T}_{0}$ & $64.18 \mathrm{c}$ & 20.57 & $76.00 \mathrm{~b}$ & $20.12 \mathrm{~b}$ & 24.95 & $20.22 \mathrm{~b}$ \\
\hline $\mathrm{T}_{1}$ & $73.73 \mathrm{ab}$ & 22.26 & $100.00 \mathrm{a}$ & $20.75 \mathrm{a}$ & 34.90 & $30.67 \mathrm{a}$ \\
\hline $\mathrm{T}_{2}$ & $69.12 \mathrm{bc}$ & 21.55 & $92.00 \mathrm{ab}$ & $20.27 \mathrm{ab}$ & 31.80 & $29.27 \mathrm{ab}$ \\
\hline $\mathrm{T}_{3}$ & 79.95 a & 21.84 & $89.00 \mathrm{ab}$ & $20.37 \mathrm{ab}$ & 32.72 & $28.33 \mathrm{ab}$ \\
\hline $\operatorname{SE}( \pm)$ & 1.629 & NS & 4.306 & 0.116 & NS & 2.1260 \\
\hline \multicolumn{7}{|c|}{ Interaction effect of fertilizer and soil } \\
\hline $\mathrm{S}_{1} \mathrm{~T}_{0}$ & 61.52 & 20.72 & 73.00 & $20.30 \mathrm{~b}$ & 23.97 & 19.53 \\
\hline $\mathrm{S}_{1} \mathrm{~T}_{1}$ & 73.48 & 21.86 & 95.00 & $20.43 \mathrm{ab}$ & 32.40 & 28.03 \\
\hline $\mathrm{S}_{1} \mathrm{~T}_{2}$ & 69.12 & 21.22 & 76.00 & $20.13 b$ & 28.23 & 24.23 \\
\hline $\mathrm{S}_{3} \mathrm{~T}_{3}$ & 76.96 & 20.86 & 88.00 & 20.07 b & 27.60 & 26.50 \\
\hline $\mathrm{S}_{2} \mathrm{~T}_{0}$ & 66.84 & 20.42 & 79.00 & 19.93 b & 25.93 & 20.90 \\
\hline $\mathrm{S}_{2} \mathrm{~T}_{1}$ & 73.97 & 22.66 & 105.00 & $21.07 \mathrm{a}$ & 37.40 & 33.30 \\
\hline $\mathrm{S}_{2} \mathrm{~T}_{2}$ & 69.13 & 21.88 & 108.00 & $20.40 \mathrm{ab}$ & 35.37 & 34.30 \\
\hline $\mathrm{S}_{2} \mathrm{~T}_{3}$ & 82.94 & 22.82 & 90.00 & $20.67 \mathrm{ab}$ & 37.83 & 30.17 \\
\hline $\mathrm{SE}( \pm)$ & NS & NS & NS & 0.1633 & NS & NS \\
\hline
\end{tabular}

In a column figure(s) having similar letter do not differ significantly at $5 \%$ level of significance as per DMRT.

Different doses of fertilizers showed significant variations in respect of grain yield. The application of fertilizers and manure had a positive effect on the grain yield of boro rice. Among the different doses of fertilizers, $\mathrm{T}_{1}$ showed the highest grain yield/core $(30.67 \mathrm{~g}$ core $^{-1}$ ) which was statistically similar with the $T_{2}$ and $T_{3}$ treatment. On the contrary, the lowest grain yield/core (20.22 $\left.\mathrm{g} \mathrm{core}^{-1}\right)$ was observed with $\mathrm{T}_{0}$ where no fertilizer was applied. Application of inorganic fertilizer and manure increased the rice yield in the findings of (Miah et al., 2006; Reddy et al. 2005; Xu et al., 2008).

The combined application of different doses of fertilizer and soils had an insignificant variation on the plant height, panicle length, filled grains panicle ${ }^{-1}$, grain and straw yields of rice (Table 1). The higher plant height, panicle length and straw yields were recorded in $\mathrm{S}_{2} \mathrm{~T}_{3}$ (Sonargaon Soil $+50 \%$ NPKS $+2.1 \mathrm{t} \mathrm{ha}^{-1}$ poultry manure) treatment. The highest number of filled grains per panicle of rice (108.00) was recorded with the treatment combination $\mathrm{S}_{2} \mathrm{~T}_{2}$ (Sonargaon Soil $+50 \%$ NPKS + 5 t cowdung/ha). The combined effect of different doses of fertilizer and soils on the straw yield of rice was insignificant. The higher straw yield $(37.83 \mathrm{~g}$ core ${ }^{-1}$ ) was recorded with the treatment combination $\mathrm{S}_{2} \mathrm{~T}_{3}$ (Sonargaon soils $+50 \%$ NPKS + 
Khan et al.

$2.1 \mathrm{t}$ poultry manure ha $\left.{ }^{-1}\right)$ and the lowest straw yield $\left(23.97 \mathrm{~g}_{\text {core }}{ }^{-1}\right)$ was found in $\mathrm{S}_{1} \mathrm{~T}_{0}$ (Soils $\mathrm{SAU}+$ control treatment) treatment combination. The highest grain yield was recorded in (34.30 g core $e^{-1}$ ) $\mathrm{S}_{2} \mathrm{~T}_{2}$ which was similar to $\mathrm{S}_{2} \mathrm{~T}_{1}$ and $\mathrm{S}_{2} \mathrm{~T}_{3}$ treatment combination. The results indicate that 50\% nutrient from inorganic fertilizer and $50 \%$ from manure can be used for boro rice cultivation.

\section{NPKS concentration in grain}

Effect of soils, fertilizer and manure on $\mathrm{N}, \mathrm{P}, \mathrm{K}$ and $\mathrm{S}$ concentration in boro rice grain

The grain N, P and K concentrations were not significantly affected by different soils. Similar grain N P and K concentrations were found in SAU and Sonargaon soils. Significant variation was observed in grain $\mathrm{S}$ concentration of rice grown in two different soils. Between these two soils, $S_{2}$ showed the higher $(0.117 \%) S$ concentration compared to grain $S(0.103 \%)$ of $S_{1}$ soil.

Table 2. Effects of soil, fertilizer and Soil Fertilizer on the N, P, K and S concentration of boro rice grain

\begin{tabular}{|c|c|c|c|c|}
\hline \multirow[t]{2}{*}{ Treatments } & \multicolumn{4}{|c|}{ Grain Nutrient Concentration (\%) } \\
\hline & $\mathrm{N}$ & $P$ & $\mathrm{~K}$ & $\mathrm{~S}$ \\
\hline \multicolumn{5}{|l|}{ Effect of soil } \\
\hline $\mathrm{S}_{1}$ & 1.155 & 0.248 & 0.269 & $0.103 \mathrm{a}$ \\
\hline $\mathrm{S}_{2}$ & 1.153 & 0.242 & 0.282 & $0.117 \mathrm{~b}$ \\
\hline $\operatorname{SE}( \pm)$ & NS & NS & NS & 0.002 \\
\hline \multicolumn{5}{|c|}{ Effect of fertilizer and manure } \\
\hline $\mathrm{T}_{0}$ & 1.050 & 0.223 & $0.231 \mathrm{~d}$ & $0.095 \mathrm{~d}$ \\
\hline $\mathrm{T}_{1}$ & 1.178 & 0.248 & $0.286 \mathrm{c}$ & $0.125 \mathrm{a}$ \\
\hline $\mathrm{T}_{2}$ & 1.205 & 0.261 & $0.296 \mathrm{a}$ & $0.105 \mathrm{c}$ \\
\hline $\mathrm{T}_{3}$ & 1.183 & 0.249 & $0.291 \mathrm{~b}$ & $0.115 \mathrm{~b}$ \\
\hline $\operatorname{SE}( \pm)$ & NS & NS & 0.0073 & 0.0041 \\
\hline \multicolumn{5}{|c|}{ Interaction effect of soil and fertilizer } \\
\hline $\mathrm{S}_{1} \mathrm{~T}_{0}$ & 0.980 & 0.226 & 0.240 & 0.086 \\
\hline $\mathrm{S}_{1} \mathrm{~T}_{1}$ & 1.210 & 0.258 & 0.276 & 0.112 \\
\hline $\mathrm{S}_{1} \mathrm{~T}_{2}$ & 1.240 & 0.272 & 0.283 & 0.102 \\
\hline $\mathrm{S}_{1} \mathrm{~T}_{3}$ & 1.190 & 0.237 & 0.279 & 0.112 \\
\hline $\mathrm{S}_{2} \mathrm{~T}_{0}$ & 1.120 & 0.220 & 0.221 & 0.104 \\
\hline $\mathrm{S}_{2} \mathrm{~T}_{1}$ & 1.147 & 0.238 & 0.296 & 0.139 \\
\hline $\mathrm{S}_{2} \mathrm{~T}_{2}$ & 1.170 & 0.251 & 0.309 & 0.108 \\
\hline $\mathrm{S}_{2} \mathrm{~T}_{3}$ & 1.177 & 0.261 & 0.303 & 0.117 \\
\hline $\mathrm{SE}( \pm)$ & NS & NS & NS & NS \\
\hline CV (\%) & 10.49 & 13.61 & 6.48 & 9.18 \\
\hline
\end{tabular}

In a column figure(s) having similar letter do not differ significantly at $5 \%$ level of significance as per DMRT.

Nitrogen and phosphorus concentrations in grain of boro rice showed statistically insignificant variation due to the application of different doses of fertilizers and manure (Table 2). The similar levels of grain $\mathrm{N}$ concentrations were recorded in all the treatments except control. The higher $\mathrm{N}(1.205 \%)$ and $\mathrm{P}(0.261 \%)$ concentrations were recorded from $\mathrm{T}_{2}(50 \% \mathrm{NPKS}+5 \mathrm{t}$ cowdung ha $\left.{ }^{-1}\right)$ which was closely followed by $\mathrm{T}_{3}\left(50 \% \mathrm{NPKS}+2.1 \mathrm{t}\right.$ poultry manure ha- $\left.{ }^{-1}\right)$ 
treatments and the lowest level was found in the grain of $T_{0}$ treatment. A significant increase in $\mathrm{N}$ and $\mathrm{P}$ content in rice grain due to the application of organic manure and fertilizers have been reported by investigators (Hoque, 1999).

Potassium and sulphur (S) concentrations in grain of rice showed statistically significant variation due to the application of different doses of fertilizers and manure. The highest $\mathrm{K}$ concentration in grain $(0.296 \%)$ was recorded in $\mathrm{T}_{2}$ treatment. Potassium content in grain was increased due to combined application of organic manure and chemical fertilizers. The higher $(0.125 \%) \mathrm{S}$ concentration in grain was recorded from $\mathrm{T}_{1}$ as $\mathrm{N}_{120} \mathrm{P}_{20} \mathrm{~K}_{45} \mathrm{~S}_{20}$ which was closely followed $(0.115 \%)$ by $\mathrm{T}_{3}$. The lower grain $\mathrm{K}(0.231 \%)$ and $\mathrm{S}(0.095 \%)$ concentrations were found from $\mathrm{T}_{0}$ treatment.

The combined effect of different doses of fertilizer and soils on $\mathrm{N}, \mathrm{P}, \mathrm{K}$ and $\mathrm{S}$ concentrations in rice grain was insignificant (Table 2). The higher grain $\mathrm{N}(1.240 \%)$ and $\mathrm{P}$ concentrations $(0.272 \%)$ were recorded with the treatment combination $\mathrm{S}_{1} \mathrm{~T}_{2}$ (SAU Soil $+50 \% \mathrm{NPKS}+5 \mathrm{t}$ ha ${ }^{1}$ cowdung). The higher $\mathrm{K}(0.309 \%)$ and $\mathrm{S}(0.139 \%)$ concentrations were recorded with the treatment combination $\mathrm{S}_{2} \mathrm{~T}_{2}$ (Sonargaon Soil $+50 \% \mathrm{NPKS}+5 \mathrm{t}$ ha ${ }^{1}$ cowdung). The lower grain $\mathrm{N}, \mathrm{P} \mathrm{K}$ and $\mathrm{S}$ concentrations were found in $\mathrm{S}_{1} \mathrm{~T}_{0}$ and $\mathrm{S}_{1} \mathrm{~T}_{0}$ treatment combination.

\section{Effect of fertilizers and manure on the leachate $\mathrm{N}, \mathrm{P}, \mathrm{K}$ and $\mathrm{S}$ concentrations during boro rice growing period}

The nutrient concentrations in the leachate were not significantly influenced by different soils while significantly affected by fertilizer treatments. The combined effect of soil and fertilizer had no significant effect on leachate $\mathrm{N}, \mathrm{P}, \mathrm{K}$ and $\mathrm{S}$ concentrations in the leachate samples of maximum dates of sampling. The applied fertilizer and manure resulted in higher NPKS concentrations in the leachate. Higher N concentrations were found in the leachate of $100 \%$ recommended a dose of chemical fertilizer $\left(\mathrm{T}_{1}\right)$ and lowest concentration was observed in the control treatment (Fig. 2).
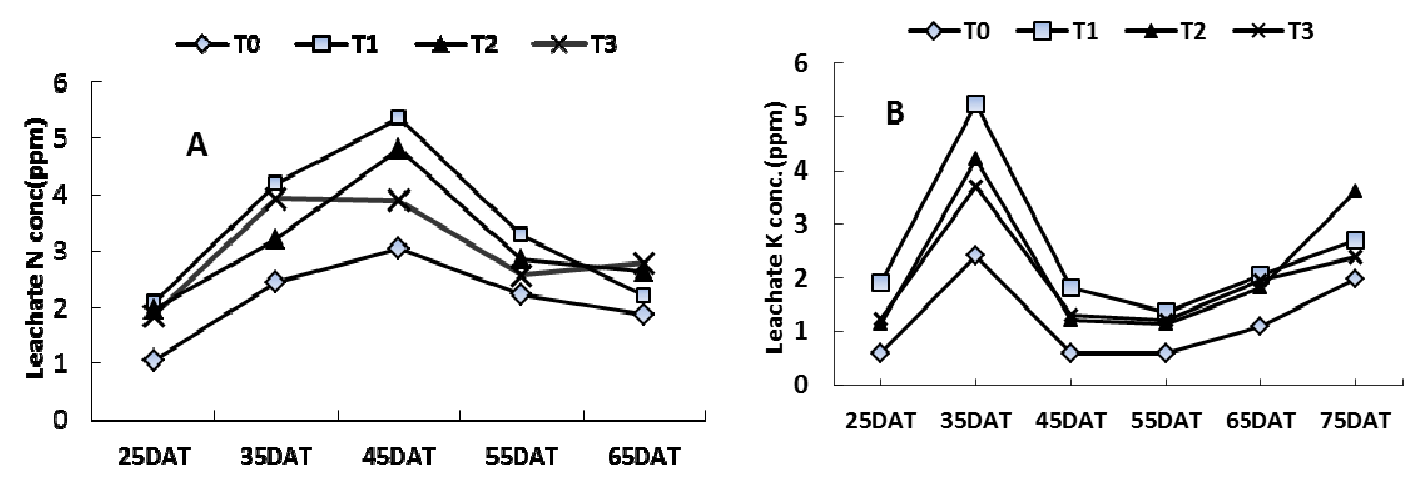

Fig. 2. Effect of fertilizer and manure on $\mathrm{N}$ and $\mathrm{K}$ conc. in the leachate of different dates of boro rice growing period. DAT (days after transplanting).

The $\mathrm{N}$ leaching increased up to $45 \mathrm{DAT}$ and after that decreased gradually and highest concentration $(5.36 \mathrm{ppm})$ was found in $\mathrm{T}_{1}$ treatment at 45 DAT. Among the fertilizer treatments, higher concentrations of $\mathrm{K}$ were found in the leachate of $100 \%$ chemical fertilizer treatment compared to other fertilizer treatments (Fig. 2). The highest $\mathrm{K}$ concentration $(5.24$ $\mathrm{ppm})$ in the leachate was found at 35 DAT with $\mathrm{T}_{1}$ treatment and lowest $\mathrm{K}$ concentrations 
Khan et al.

were found from the control. Chemical fertilizer was more leachable from the soil solution than organic plus inorganic fertilizer treatments due to adsorption to organic and inorganic colloids and slow release of nutrient from manure. The higher $\mathrm{K}$ concentrations were found in the leachate of 35 DAT and then almost similar trend was observed. When fertilizer was applied initially more leachable $\mathrm{K}$ was present in the leachate firstly, and after 35 days soluble $\mathrm{K}$ was fixed on the soil colloidal surface.

The fertilizer application did not affect the leachate-P concentrations significantly and the leachate-P concentrations were relatively low with all soils, fertilizer treatments and different time of sampling. Higher leachate $\mathrm{P}$ concentrations were found in the $\mathrm{T}_{1}, \mathrm{~T}_{2}$ and $\mathrm{T}_{3}$ treatments where fertilizer and manure were applied (Fig.3). The leachate P concentration increased at 35 DAT and then decreased. Among the fertilizer treatments, higher levels of $\mathrm{S}$ concentrations were recorded in the leachate of two combined treatment where cowdung or poultry manure were used with $50 \%$ chemical fertilizer (Fig.3). The highest concentration of $4.21 \mathrm{ppm} \mathrm{S}$ was obtained at 55 DAT from the $\mathrm{T}_{3}$ treatment where $50 \%$ inorganic fertilizer and 2.1 ton poultry manure ha ${ }^{-1}$ were applied. The lowest $S$ concentration $(0.83 \mathrm{ppm})$ was obtained from the control treatment.
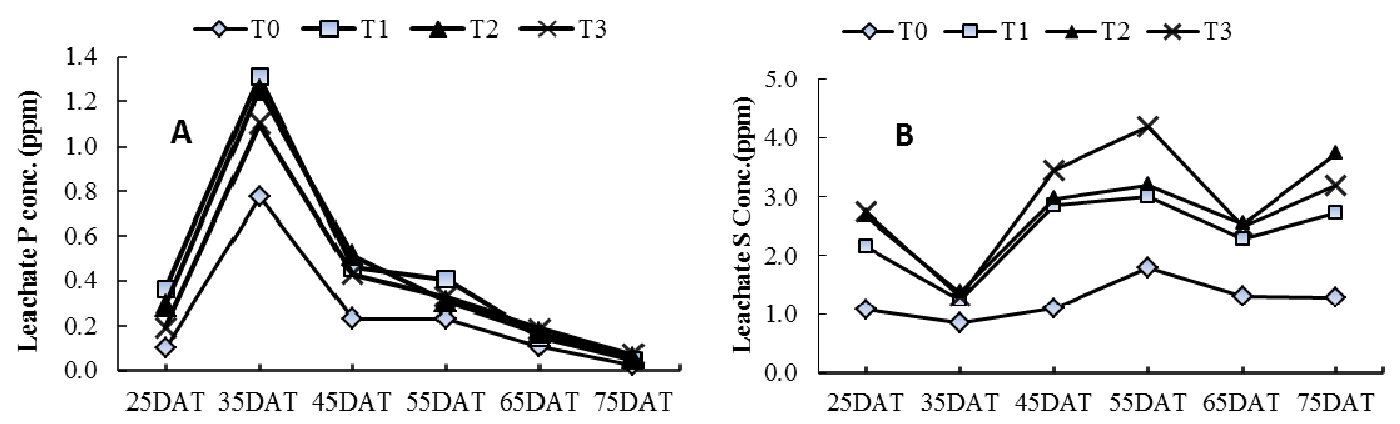

Fig. 3. Effect of fertilizer and manure on $\mathrm{N}$ and $\mathrm{K}$ conc. in the leachate of different dates of boro rice growing period

Effect of soil, fertilizer and manure on $\mathrm{pH}$ and NPKS concentrations in post-harvest soil Between two soils, Sonargaon soil showed higher pH (7.3) than SAU soil pH (6.8) at 0-10 cm depth of post-harvest soil. Almost similar soil $\mathrm{pH}$ values were found at $10-20 \mathrm{~cm}$ depth of postharvest soils of SAU and Sonargaon. SAU soil showed the higher total N concentration $(0.08 \%)$ at $0-10 \mathrm{~cm}$ depth compared to the soil of $10-20 \mathrm{~cm}$ depth. Similar N-conc. was found in the depth of $(0-10) \mathrm{cm}$ and $(10-20) \mathrm{cm}$ of Sonargaon soil. The available $\mathrm{P}$ and $\mathrm{K}$ concentrations varied significantly with soil and higher levels of $\mathrm{P}$ concentrations were found in SAU soil than Sonargaon soil. In both the soils levels of $\mathrm{P}$ decreased with increasing soil depth may be due to more applied $\mathrm{P}$ fixation with the top soils. The highest available $\mathrm{P}$ concentration (26.77 ppm) was found at a depth of $0-10 \mathrm{~cm}$ of SAU Soil and lowest $(15.02 \mathrm{ppm})$ in the depth of $10-20 \mathrm{~cm}$ of Sonargaon soil. The higher concentrations of available $\mathrm{K}$ were found in the SAU soil compared to Sonargaon soil and similar levels of $\mathrm{K}$ were obtained in the depth of $0-10 \mathrm{~cm}$ and $10-20 \mathrm{~cm}$ of each soil may be due to higher mobility of applied $\mathrm{K}$ in both the soils. Available sulfur in the post-harvest soil showed statistically significant variations in different soils and higher $S$ concentrations were found in the Sonargaon soil in both the depths compared to SAU soil. Lower and similar levels of $S$ concentrations were found at 0-10 and $10-20 \mathrm{~cm}$ depths of SAU soil but the level of $\mathrm{S}$ decreased with increasing depth of Sonargaon 
soil (Table 3). The depth wise observed variability of $\mathrm{S}$ may be the cause of the difference of physico-chemical properties of soil.

The $\mathrm{pH}$ of $0-10 \mathrm{~cm}$ depth of post-harvest soil showed insignificant variation due to the application of different doses of fertilizers (Table 3). The $\mathrm{pH}$ of $10-20 \mathrm{~cm}$ depth of post-harvest soil was significantly affected by different soils. Almost similar soil $\mathrm{pH}$ was found at $10-20 \mathrm{~cm}$ depth of post-harvest soil of SAU and Sonargaon soils.

Total $\mathrm{N}$, available $\mathrm{P}, \mathrm{K}$ and $\mathrm{S}$ concentrations in post-harvest soil showed statistically significant differences due to the application of different manure and fertilizer in rice. The level of total $\mathrm{N}$ in post-harvest soil slightly increased due to combined application of fertilizer and manure. The slightly higher $(0.09$ and $0.08 \%)$ total $\mathrm{N}$ concentrations were found in the post-harvest soils of $(0-10) \mathrm{cm}$ and $(10-20) \mathrm{cm}$ depths where $\mathrm{T}_{2}$ (50\% NPKS +5 ton cowdung/ha) treatment was applied during T.Aman and Boro season.

Table 3. Effects of soil, fertilizer and Soil $\times$ Fertilizer on the $\mathrm{pH}, \mathrm{N}, \mathrm{P}, \mathrm{K}$ and $\mathrm{S}$ content in postharvest soil

\begin{tabular}{|c|c|c|c|c|c|c|c|c|c|c|}
\hline \multirow[t]{3}{*}{ Treatments } & \multicolumn{2}{|c|}{ Soil pH } & \multicolumn{2}{|c|}{ Total N (\%) } & \multicolumn{2}{|c|}{ Available P (ppm) } & \multicolumn{2}{|c|}{ Available K (ppm) } & \multicolumn{2}{|c|}{ Available S (ppm) } \\
\hline & $(0-10)$ & $(10-20)$ & $(0-10)$ & $(10-20)$ & $(0-10)$ & $(10-20)$ & $(0-10)$ & $(10-20)$ & $(0-10)$ & $(10-20)$ \\
\hline & $\mathrm{cm}$ & $\mathrm{cm}$ & $\mathrm{cm}$ & $\mathrm{cm}$ & $\mathrm{cm}$ & $\mathrm{cm}$ & $\mathrm{cm}$ & $\mathrm{cm}$ & $\mathrm{cm}$ & $\mathrm{cm}$ \\
\hline \multicolumn{11}{|l|}{ Effect of soil } \\
\hline $\mathrm{S}_{1}$ & $6.8 \mathrm{a}$ & $7.2 \mathrm{a}$ & $0.08 a$ & 0.07 & $26.77 a$ & $22.63 a$ & $17.79 a$ & $17.37 \mathrm{a}$ & $19.82 \mathrm{a}$ & $18.79 a$ \\
\hline $\mathrm{S}_{2}$ & $7.3 \mathrm{~b}$ & $7.6 \mathrm{~b}$ & $0.07 b$ & 0.07 & $18.52 b$ & $15.02 b$ & $12.13 b$ & $12.29 b$ & $29.36 b$ & $24.42 b$ \\
\hline $\operatorname{SE}( \pm)$ & 0.042 & 0.015 & 0.001 & NS & 1.4383 & 0.751 & 0.833 & 0.712 & 0.790 & 0.796 \\
\hline \multicolumn{11}{|c|}{ Effect of fertilizer and manure } \\
\hline $\mathrm{T}_{0}$ & 7.2 & $7.2 \mathrm{c}$ & $0.06 \mathrm{~d}$ & $0.06 c$ & $14.92 b$ & $13.87 \mathrm{c}$ & $9.75 b$ & $10.58 \mathrm{c}$ & $13.43 c$ & $13.88 \mathrm{c}$ \\
\hline $\mathrm{T}_{1}$ & 6.9 & $7.5 \mathrm{a}$ & $0.07 c$ & $0.07 b$ & $24.66 a$ & $16.74 b c$ & $16.25 a$ & $13.92 b c$ & $25.78 b$ & $20.94 b$ \\
\hline $\mathrm{T}_{2}$ & 7.1 & $7.4 \mathrm{~b}$ & $0.09 a$ & $0.08 \mathrm{a}$ & $27.19 a$ & $23.56 a$ & $14.58 \mathrm{ab}$ & $16.33 \mathrm{ab}$ & $25.37 b$ & $25.05 \mathrm{ab}$ \\
\hline $\mathrm{T}_{3}$ & 7.1 & $7.5 \mathrm{ab}$ & $0.08 b$ & $0.07 b$ & $23.87 \mathrm{ab}$ & $21.15 \mathrm{ab}$ & $19.25 \mathrm{a}$ & $18.50 \mathrm{a}$ & $33.78 \mathrm{a}$ & $26.54 a$ \\
\hline $\mathrm{SE}( \pm)$ & NS & 0.021 & 0.002 & 0.001 & 2.034 & 1.067 & 1.178 & 1.007 & 1.117 & 1.126 \\
\hline \multicolumn{11}{|c|}{ Interaction effect of soil and fertilizer } \\
\hline $\mathrm{S}_{1} \mathrm{~T}_{0}$ & 6.9 & $6.9 c$ & $0.060 e$ & $0.070 b$ & 19.58 & 17.04 & $9.50 c$ & 11.67 & $11.56 e$ & $12.69 e$ \\
\hline $\mathrm{S}_{1} \mathrm{~T}_{1}$ & 6.7 & $7.4 \mathrm{~b}$ & $0.077 b$ & $0.070 b$ & 29.55 & 20.43 & $20.00 \mathrm{ab}$ & 16.67 & $22.92 \mathrm{~d}$ & $19.79 \mathrm{cde}$ \\
\hline $\mathrm{S}_{1} \mathrm{~T}_{2}$ & 6.8 & $7.1 \mathrm{c}$ & $0.097 a$ & $0.077 a$ & 28.52 & 26.37 & $16.67 \mathrm{bc}$ & 20.83 & $14.58 e$ & $19.48 \mathrm{cde}$ \\
\hline $\mathrm{S}_{1} \mathrm{~T}_{3}$ & 6.8 & $7.3 \mathrm{~b}$ & $0.077 \mathrm{~b}$ & $0.077 a$ & 29.53 & 26.70 & $25.00 a$ & 20.33 & $30.21 b c$ & $23.19 b c$ \\
\hline $\mathrm{S}_{2} \mathrm{~T}_{0}$ & 7.5 & $7.4 \mathrm{~b}$ & $0.070 \mathrm{c}$ & $0.060 \mathrm{c}$ & 10.25 & 10.70 & $10.00 \mathrm{c}$ & 9.50 & $15.29 e$ & $15.06 \mathrm{dc}$ \\
\hline $\mathrm{S}_{2} \mathrm{~T}_{1}$ & 7.2 & $7.6 \mathrm{a}$ & $0.067 \mathrm{~d}$ & $0.077 a$ & 19.78 & 13.05 & $12.50 \mathrm{bc}$ & 11.17 & $28.65 \mathrm{~cd}$ & $22.08 \mathrm{~cd}$ \\
\hline $\mathrm{S}_{2} \mathrm{~T}_{2}$ & 7.4 & $7.6 \mathrm{a}$ & $0.077 \mathrm{~b}$ & $0.077 a$ & 25.85 & 20.74 & $12.50 \mathrm{bc}$ & 11.83 & $36.15 \mathrm{ab}$ & 30.63a \\
\hline $\mathrm{S}_{2} \mathrm{~T}_{3}$ & 7.2 & $7.7 \mathrm{a}$ & $0.077 \mathrm{~b}$ & $0.070 b$ & 18.21 & 15.60 & $13.50 \mathrm{bc}$ & 16.67 & $37.35 a$ & $29.90 \mathrm{ab}$ \\
\hline $\mathrm{SE}( \pm)$ & NS & 0.030 & 0.002 & 0.0018 & NS & NS & 1.666 & 1.424 & 1.579 & 1.5923 \\
\hline CV (\%) & 2.08 & 0.72 & 3.56 & 4.28 & 21.99 & 13.81 & 19.29 & 16.62 & 11.12 & 12.77 \\
\hline
\end{tabular}

In a column figure(s) having similar letter do not differ significantly at $5 \%$ level of significance as per DMRT.

The level of available $\mathrm{P}, \mathrm{K}$ and $\mathrm{S}$ in post-harvest soil increased due to the application of fertilizer and manure. The higher levels of post-harvest soil available $P$ were recorded at $0-10 \mathrm{~cm}(27.19$ $\mathrm{ppm})$ and $10-20 \mathrm{~cm}(23.56 \mathrm{ppm})$ depths with $\mathrm{T}_{2}\left(50 \% \mathrm{NPKS}+5 \mathrm{t}_{\text {cowdung ha }}{ }^{-1}\right)$ treatment. The level $\mathrm{P}$ increased more only in the depth of $0-10 \mathrm{~cm}$ by using $100 \%$ chemical fertilizer but lower concentration was noticed in the depth of $10-20 \mathrm{~cm}$ due to more $\mathrm{P}$ fixation of chemical fertilizer in the upper layer soil. Higher amounts of $P$ moved to $10-20 \mathrm{~cm}$ depth where fertilizer and manure were applied may be due to reducing the fixing capacity of soil by application of 
Khan et al.

manure. Avoola and Makinde (2009) found that application of chemical fertilizer with organic manure increase $\mathrm{N}$ and $\mathrm{P}$ content in post-harvest soil. The post-harvest soil of $\mathrm{T}_{3}$ (50\% NPKS $+2.1 \mathrm{t}$ poultry manure ha ${ }^{-1}$ ) treatment gave the higher levels of $\mathrm{K}$ and $\mathrm{S}$ concentration in the soils of $0-10 \mathrm{~cm}$ and $10-20 \mathrm{~cm}$ depths. Higher concentrations of N, P, K and S were found in different depths of post-harvest soils where fertilizer plus manure were applied due to positive effects of applied manure in combination with fertilizer (Table 3).

The $\mathrm{pH}$ at $10-20 \mathrm{~cm}$ depth of post-harvest soil was significantly influenced by interaction effect of different soils and fertilizer and the $\mathrm{pH}$ values were more increased in the depths of 10-20 $\mathrm{cm}$ in comparison to $0-10 \mathrm{~cm}$ depth. The higher levels of $\mathrm{pH}$ of post-harvest soils were recorded in the fertilizer applied treatments of both the soils. The $\mathrm{pH}$ of SAU soil was more increased with the application of different fertilizer, manure may be due to increasing leaching losses of basic cations from the soil. The higher $\mathrm{pH}$ (7.7) of post-harvest soil was recorded with the treatment combination $\mathrm{S}_{2} \mathrm{~T}_{3}$ (Sonargaon Soil $+50 \% \mathrm{NPKS}+2.1 \mathrm{t} \mathrm{ha}^{-1}$ poultry manure) treatment. Almost similar $\mathrm{N}$ concentrations were found at a depth of $0-10$ and $10-20 \mathrm{~cm}$, the higher $(0.097 \%)$ total $\mathrm{N}$ concentration was found in $\mathrm{S}_{1} \mathrm{~T}_{2}$ (SAU Soil $+50 \% \mathrm{NPKS}+5 \mathrm{t}$ ha ${ }^{-1}$ cowdung) treatment combination and lowest $(0.060 \%)$ was obtained from $\mathrm{S}_{1} \mathrm{~T}_{0}$ (SAU Soil + control treatment) treatment combination. Higher levels of $\mathrm{P}$ were found in the depths of $0-10$ $\mathrm{cm}$ than 10-20 $\mathrm{cm}$ where chemical fertilizer was applied in SAU soil $\left(\mathrm{S}_{1} \mathrm{~T}_{1}\right)$. The level of $\mathrm{P}$ more increased in the depths of $0-10 \mathrm{~cm}$ and $10-20 \mathrm{~cm}$ of SAU soil where inorganic fertilizer and manure were applied. The organic matter influenced the level of P increasing at $10-20 \mathrm{~cm}$ depth. The combined effect of fertilizer and soils significantly influenced the $\mathrm{K}$ and $\mathrm{S}$ content in post-harvest soil and higher levels of $\mathrm{K}$ were found in the SAU soil compared to Sonargaon soil where fertilizer and manure were applied. The highest available potassium concentration was obtained at $0-10 \mathrm{~cm}$ of $\mathrm{S}_{1} \mathrm{~T}_{3}$ (SAU Soil $+2.1 \mathrm{t} \mathrm{ha}^{-1}$ poultry manure) treatment combinations and lowest $(9.50 \mathrm{ppm})$ from $\mathrm{S}_{1} \mathrm{~T}_{0}$ (SAU Soil + No fertilizer). Higher levels of $\mathrm{S}$ were found in the Sonargaon soil compared to SAU soil where fertilizer and manure were applied. In the soil of $0-10 \mathrm{~cm}$, the highest available sulfur concentration $(37.35 \mathrm{ppm})$ was obtained from $\mathrm{S}_{2} \mathrm{~T}_{3}$ (Sonargaon Soil $+2.1 \mathrm{t}$ poultry manure ha $\left.{ }^{-1}\right)$ treatment combinations and lowest (11.56 ppm) from $\mathrm{S}_{1} \mathrm{~T}_{0}$ (SAU Soil + No fertilizer) treatment combination. Similarly in the depth of (10-20) $\mathrm{cm}$, the higher $(30.63 \mathrm{ppm})$ available $\mathrm{S}$ in post-harvest soils were obtained from $\mathrm{S}_{2} \mathrm{~T}_{2}$ (Sonargaon Soil $+50 \%$ NPKS +5 t cowdung ha ${ }^{-1}$ ) and the lower (12.69 ppm) available S concentration was found from $\mathrm{S}_{1} \mathrm{~T}_{0}$ (SAU Soil + No fertilizer) treatment combination.

\section{Conclusion}

Higher $\mathrm{N}$ and $\mathrm{K}$ leaching were obtained in the undisturbed column where chemical fertilizers were used for boro cultivation. Applications of organic plus inorganic fertilizer are recommended for reducing leaching, increasing soil fertility, nutrient accumulation and yield of boro rice. Higher N P and K leaching were observed during 30 to 45 days after transplantation of boro rice. The application of organic matter increased more the level of $\mathrm{P}$ and $\mathrm{S}$ at $0-10 \mathrm{~cm}$ and 10-20 cm depths for increasing mobility. The almost similar levels of $\mathrm{N}$ and $\mathrm{K}$ were found in the initial and post-harvest soil due to higher leaching.

\section{Acknowledgement}

The authors gratefully acknowledge the financial support of Ministry of Science and Technology (Bangladesh) to conduct this research. 


\section{References}

Anderson, B. H. and F. R. Magdoff, 2005. Relative movement and soil fixation of soluble organic and inorganic phosphorus. J. Environ. Qual. 34(6): 2228-33.

BBS (Bangladesh Bureau of Statistics). 2008. Statistical Yearbook of Bangladesh. Statistics Division, Ministry of Planning, Gout. of Peoples Republic of Bangladesh. Dhaka. Bangladesh. p. 71.

Bouyoucos, G. J. 1926. Hydrometer method improved for making particle size analysis of soils. Agron. J. 54: 4661-4665.

Fagaria, N. K., G. D. Carvalho, A. B. Santo, E. P. B. Ferreira and A. M. Knupp, 2011. Chemistry of lowland rice soils and nutrient availability. Commun. Soil Sci. Plant Anal. 42: 19131933.

Gomez, K. A. and A. A. Gomez, 1984. Statistical Procedures for Agricultural Research. Jhon Wiley and Sons, New York.

Guntinas, M. E., M. C. Leiros, C. Trasar, F. Trasar-Cepeda and G. Sotres, 2012. Effects of moisture and temperature on net soil nitrogen mineralization. Euro. J. Soil Biol.48: 73-80.

Hoque, S. A. 1999. Nutrient requirements of wet land rice production. Proc. Int. Symp. On Paddy soils, September 15-19, Beijing, China Academia Sinica. 281-282.

Jackson, M. L. 1962. Soil Chemical Analysis. Constable and Co. Ltd London.

Jalali, M. and D. Rowell, 2009. Displacement studies on leaching of potassium. Environ. Geo. 57(1): 4148-4155.

Miah, M. A. M., M. Ishaque and P. K. Saha, 2006. Integrated nutrient management for improving soil health and rice production. Proc. of twenty first BRRI-DAE joint workshops on bridging the rice yield gap for food security. BRRI, Gazipur, Bangladesh, 19-21 Sept., paper. 11: 115.

Olsen, S. R., C. V. Cole, F. S. Watanabe and L. A. Dean, 1954. Estimation of available phosphorus in soils by extraction with sodium bicarbonate, U.S. Dept. Agric. Circ. p. 929.

Page, A. L., R. H. Miller and D. R. Keeney, (ed). 1982. Methods of soil analysis part 2, Chemical and Microbiological Properties, Second Edition American Soc. of Agron., Inc., Soil Sci. Soc. of American Inc. Madson, Wisconsin, USA. pp. 403-430.

Rahman, M. S., M. R. Islam, M. M. Rahman and M. I. Hossain, 2009. Effect of cowdung, poultry manure and urea-N on the yield and nutrient uptake of BRRI dhan 29. Bangladesh Res. Pub. J. 2: 552-558.

Reddy, B. G. M., P. S. Pattar and P. H. Kuchanur, 2005. Response of rice to poultry manure and graded levels of NPK under irrigated conditions. Oryza. 42(2): 109-111.

Walkley, A. and D. R. Black, 1935. An examination of the digestion method for determining soil organic matter and proposed modification of the chronic acid titration method. Soil Sci. 37: 29-38.

Xu, M. G., D. C. Li, J. M. Li, D. Z. Qin, Yagikazuyuki and Y. Hosen, 2008. Effects of organic manure application with chemical fertilizers or Nutrient Absorption and yield of Rice in Hunan of Southern China. Agri. Sci. China. 7 (10): 1245-1252.

Yang, C. M., L. Yang, Y. Yang and Z. Ouyang, 2004. Rice root growth and nutrient uptake as influenced by organic manure in continuously and alternately flooded paddy soils. Agric. Water. Manag. 70 (1): 67-81. 